\title{
On Purified M-Actomyosin of Squid Muscle
}

\author{
Juichiro J. Matsumoto \\ (Tokai Regional Fisheries Research Laboratory)
}

In the previous work ${ }^{1)}$, it was reported that response of streaming birefringence (SB) of $\mathrm{M}$-actomyosin, an actomyosin-like protein of squid muscle, responds to the addition of adenosinetriphosphate (ATP) and that the adenosinetriphosphatase (ATPase) activity of $\mathrm{M}$-actomyosin which functioned during the ATP-response appeared not to be inhibited by the presence of $\mathrm{Mg}$ ion. Though the effect of bivalent metallic ions such as $\mathrm{Ca}$ and $\mathrm{Mg}$ ions on ATPase activity is very complicated, a greater number of the investigators share an opinion that there are two kinds of muscle ATPase, a water-soluble, Mg-activated ATPase as well as another ATPase inherent to myosin, which is activated by $\mathrm{Ca}$ but inactivated by $\mathrm{Mg}^{2 / 3) 455}$. Hence the ATPase activity of $\mathrm{M}$-actomyosin seems distinct from that of myosin and actomyosin of rabbit regarding to the effect of $\mathrm{Mg}$ ion. However, as the preparation of M-actomyosin studied previously might have been contaminated with the former of these ATPases, further study is needed with a preparation freed from the water-soluble ATPase.

The present paper includes the responses of SB and viscosity to the addition of ATP as well as the phenomenon of superprecipitation with special interest to the effect of $\mathrm{Mg}$ ion, using a preparation presumably freed from the water-soluble ATPase by repeated precipitations.

\section{Experimental}

\section{Methods}

Unless otherwise stated, methods employed were the same as the previous paper ${ }^{1)}$.

Preparation: In the previous work, M-actomyosin was precipitated from the aqueous extracts obtained by a number of repeated extraction. It was found later that use of a larger amount of water, 20 30 times the weight of muscle (v./w.), in the third extraction was more convenient, allowing the extraction of a good amount of the streaming birefringent proteins so that further repetition of extraction was dispensable. Moreover, while in the previous paper, by analogy of the salting-in range of rabbit actomyosin, $\mathrm{M}$-actomyosin precipitate was collected by dialysing overnight the aqueous extract against $0.3 \mathrm{M} \mathrm{KCl}$, it was also found later that this protein precipitated only by addition of $\mathrm{KCl}$ to $0.05 \sim 0.1 \mathrm{M}$. So in this time the precipitate was collected first at $0.05 \mathrm{M} \mathrm{KCl}$ and reprecipitated at $0.3 \mathrm{M} \mathrm{KCl}$ at which the dialysis in the previous work was done. The whole course of

Recevied Oct. $5,1957$.

Contribution B No 275, from the Tokai Regional Fisheries Research Laboratory, Tokyo. 
the preparation was as follows :

A very fresh squid, Ommastrephes sloani pacificus STEenstrup, purchased in whole sale market was skinned and its mantle muscle was minced. To $40 \mathrm{~g}$. of the mince, $280 \mathrm{ml}$. of redistilled water was added, extracted for $10 \mathrm{~min}$. by aid of a glass-stirrer, and centrifuged. The residue was reextracted with $240 \mathrm{~m} l$. of water and further with 800 $\mathrm{m} l$. as before. From the second and the third extracts which were both streaming birefringent, the latter, showing a very intense $\mathrm{SB}$, was taken and recrystallized $\mathrm{KCl}$ added was so that a concentration of $0.05 \mathrm{M}$. was attained. The mixture which was taken 1 hour after adding $\mathrm{KCl}$ was centrifuged for $30 \mathrm{~min}$. at 4,000 r.p.m. $(1,500 \sim 2,800 \mathrm{~g})$. The sediment was dissolved into $0.6 \mathrm{M} \mathrm{KCl}$ solution, precipitated twice by diluting it to $0.3 \mathrm{M} \mathrm{KCl}$, and the protein was made up to a solution at $0.5 \mathrm{M}$ or $0.6 \mathrm{M} \mathrm{KCl}(\mathrm{pH} 6.4 \sim 6.6)$, insoluble matter being removed by centrifugation after a night cold storage. The sample thus prepared was viscous and highly opalescent, showing an intense SB. Protein concentration was 2.1 $\sim 2.6 \mathrm{mg} . / \mathrm{ml}$, and yield, $1.6 \sim 2.3 \%$ of total muscle proteins.

Streaming birefringence (SB): The apparatus shown by OKADA and TADA ${ }^{6}$ ) was used. In a series of repeating twofold dilutions of the sample solution with $0.6 \mathrm{M} \mathrm{KCl}$, the lowest protein concentration for showing + pattern of SB was determined and response to added ATP was studied using the protein solution of this concentration. To $10 \mathrm{~m} l$. of the protein solution, $0.2 \mathrm{~m} l$. of $0.25 \mathrm{M} \mathrm{MgCl}_{2}$ or water, and $1 \mathrm{~m} l$. of $0.020 \mathrm{M}$ ATP were added and SB was pursued.

The final concentration of $\mathrm{Mg}$ ion in the above mixtures and also the final concentrations of $\mathrm{Mg}$ and $\mathrm{Ca}$ ions in the mixtures for the viscosity experiment, were adjusted to $0.001 \mathrm{M}$, where the $\mathrm{Mg}$ ion is said to show an inhibitory effect while the $\mathrm{Ca}$ ion an activating one to the ATPase of myosin and actomyosin of rabbit in the presence of $0.5 \sim 0.6$ $\left.\mathrm{M} \mathrm{KCl}{ }^{2) 3}{ }^{2}\right)$.

Viscosity : Two OsTwALD viscometers (capillary diameter, $0.7 \mathrm{~mm}$; capillary length, $93 \mathrm{~mm}$. and $95 \mathrm{~mm}$; volume of the bulb, $1.92 \mathrm{cc}$. and $2.06 \mathrm{cc}$; time of outllow for 0.5 $\mathrm{M} \mathrm{KCl}$ at $25^{\circ} \mathrm{C}$., $12.0 \mathrm{sec}$. and $13.7 \mathrm{sec}$.) were used. To $5 \mathrm{ml}$. of the protein solution, $0.1 \mathrm{~m} l$. of water, $0.02 \mathrm{M} \mathrm{MgCl}_{2}$ or $0.02 \mathrm{M} \mathrm{CaCl}_{2}$ were added, and then after the viscometer was placed in a thermostat at $25^{\circ} \mathrm{C}$. for $5 \sim 10 \mathrm{~min}$., $0.5 \mathrm{~m} l$. of $0.028 \mathrm{M}$ ATP solution was added and the change of viscosity was examined.

Superprecipitation: One volume of the protein solution in $0.5 \mathrm{M} \mathrm{KCl}$, was diluted with 3 volumes of water and 1 volume of veronal acetate buffer $(I=0.1, \mathrm{pH} \mathrm{6.3})$, and the protein was brought to a suspended state in a medium of 0.12 ionic strength. To 1 $\mathrm{m} l$. of this suspension $0.02 \mathrm{~m} l$. of water, $\mathrm{M} / 20 \mathrm{MgCl}_{2}$, or $\mathrm{M} / 20 \mathrm{CaCl}_{2}$, and $0.1 \mathrm{~m} l$. of $0.028 \mathrm{M}$ ATP solution were added and the change that followed was examined.

ATP sample : ATP-Na $\mathrm{Na}_{4}$ of zellstofffabrik was dissolved and used immediately. The purity estimated from $\triangle 7 \mathrm{P}$ was $80 \%$.

\section{Results}

(A) Res ponse of $S B$ to $A T P$ (Fig. 1)

The solution of M-actomyosin itself showed SB at the concentration used in the ex- 
periment. If ATP was added to the solution at room temperature, SB disappeared instantly, restored (recovered) to an extent within 5 min., and SB as intense as that before adding ATP was observed $7 \mathrm{~min}$. after the addition of ATP (Curve B). This consequence was almost the same as that of the previous study. When $\mathrm{MgCl}_{2}$ was added, there was found a delay in the restoration of $\mathrm{SB}$, and as late as 20 min. after adding ATP, SB was judged as + pattern, whereas this + pattern was rather inferior in intensity to the + pattern observed before the addition of ATP. SB, however, could not be observed when it was examined $50 \mathrm{~min}$. after the addition of ATP (Curve C).

In another experiment, wherein the sample solution was kept in contact with ice and occasionally taken out for examina-

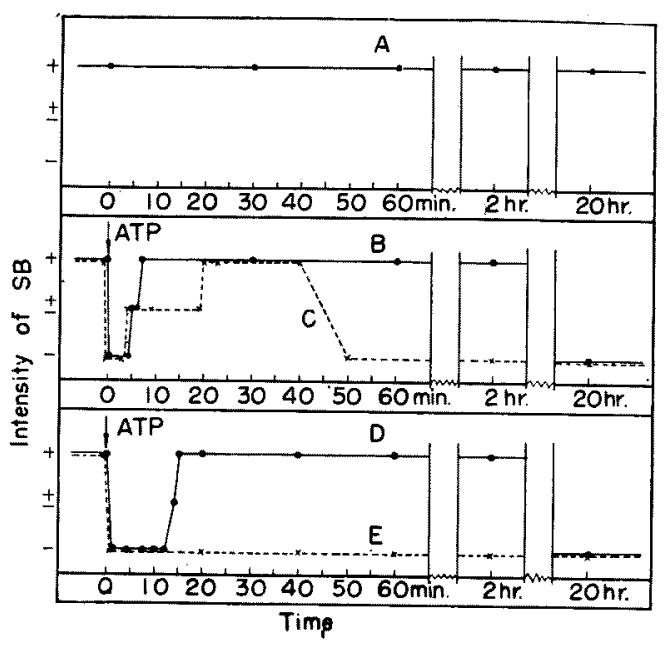

Fig. 1. Changes of $\mathrm{SB}$ of purified $\mathrm{M}$-actomyosin in $0.6 \mathrm{M} \mathrm{KCl}$ upon addition of ATP.

$\begin{array}{llllll} & \text { A } & \text { B } & \text { C } & \text { D } & \text { E } \\ \text { Protein concn, } & & & & & \\ \text { ATP }\left(\times 10^{-3} \mathrm{M}\right) & 1.2 & 1.2 & 1.2 & 1.2 & 1.2 \\ \mathrm{MgCl}_{2}\left(\times 10^{-3} \mathrm{M}\right) & - & 1.8 & 1.8 & 1.8 & 1.8 \\ \text { pH } & 6.4 & 6.4 & 6.4 & 6.5 & 6.5 \\ \text { Temperature, }^{\circ} \mathrm{C} . & 17 & 17 & 17 & \sim 0 & \sim 0\end{array}$
tion of $\mathrm{SB}$, it took about $15 \mathrm{~min}$. before $\mathrm{SB}$ restored (Curve D). In the presence of $\mathrm{Mg}$ ion and at a low temperature as well the once-disappeared SB was never found again, even over the following 2 hours (Curve E). When examined after a night, all samples ever subjected to ATP addition showed no $S B$ (Curves $B \sim E$ ), while $S B$ was invariably found in the sample that was never added with ATP (Curve A).

These results suggest that the sample studied here also undergoes the dissociation as shown in Equation (1) which was referred to in the previous paper.

$$
\text { actomyosin } \stackrel{\text { ATP }}{\longrightarrow} \text { actin }+ \text { myosin }
$$

In addition, the present data might suggest that the ATPase activity of $\mathrm{M}$-actomyosin is depressed at low temperature and also in the presence of $\mathrm{Mg}$ ion, and thus the recombination of $\mathrm{M}$-actomyosin as a result of enzymatic decomposition of ATP is inhibited by the same factors. The amount of the ATP added here was $150 \mathrm{~g}$. mole per $10^{5} \mathrm{~g}$. protein.

\section{(B) Res ponse of viscosity to $A T P$ (Fig. 2)}

To trace the dissociation of actomyosin with ATP, the response of viscosity had been used more often by investigators, because the latter method is more suited to deal with the data quantitatively. So, in order to confirm the result of SB-response, the response of the protein viscosity to the ATP in $0.5 \mathrm{M} \mathrm{KCl}$ alone, as well as in the presence of $\mathrm{MgCl}_{2}$ or $\mathrm{CaCl}_{2}$ were examined using another lot of preparation.

* In the experiment on SB-response above, $\mathrm{KCl}$ concentration was $0.6 \mathrm{M}$ with the intention of checking up the previous work. In the experiment on viscosity, however, the salt concentration was reduced to $0.5 \mathrm{M}$ because it was suggested by later observations that $\mathrm{M}$-actomyosin is rather stable at lower ionic strengths. 


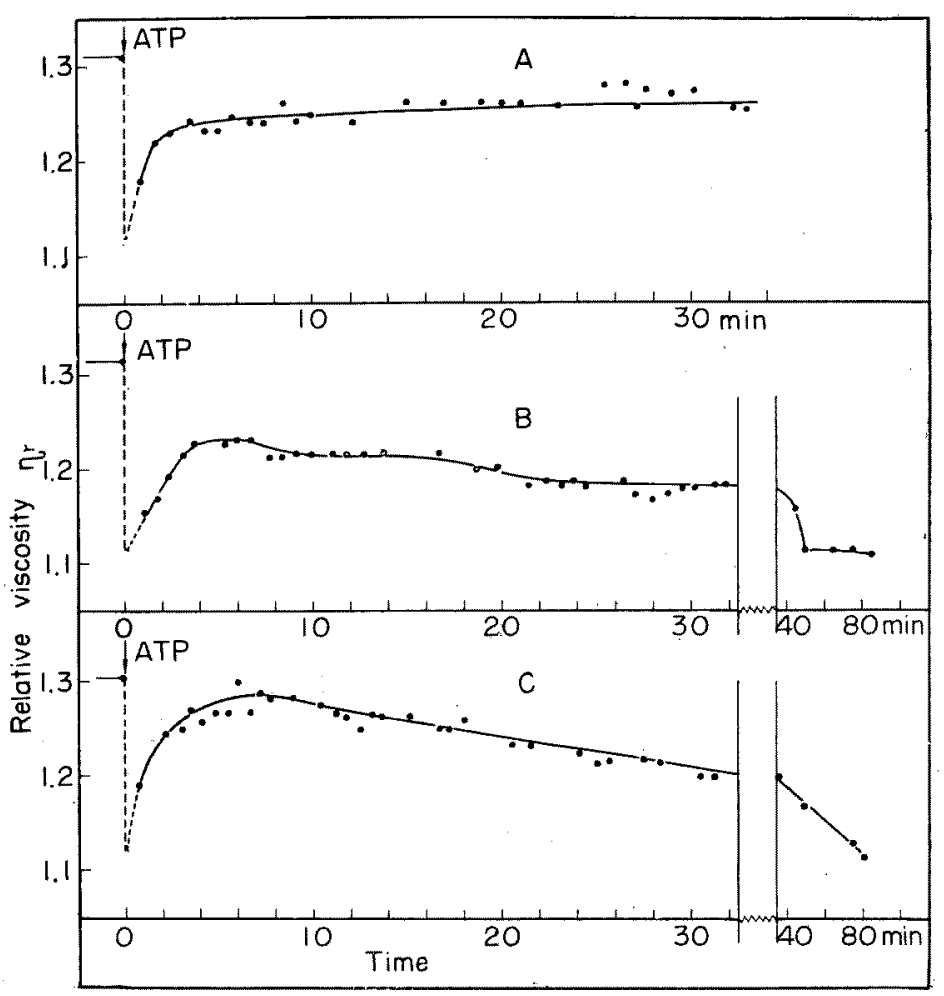

Fig. 2. Changes of viscosity of purified $\mathrm{M}$-actomyosin in $0.5 \mathrm{M} \mathrm{KCl}$ upon addition of ATP.

$\begin{array}{llll} & & & \\ \text { Protein concn. mg. } / \mathrm{ml} . & 2.0 & 2.0 & \mathrm{C} \\ \mathrm{ATP}\left(\times 10^{-3} \mathrm{M}\right) & 2.5 & 2.5 & 2.5 \\ \mathrm{MgCl}_{2}\left(\times 10^{-3} \mathrm{M}\right) & - & 1 & - \\ \mathrm{CaCl}_{2}\left(\times 10^{-3} \mathrm{M}\right) & \overline{\mathrm{MH}} & -5.5 & 1 \\ \mathrm{pH} & 6.5 & 6.4 & 6.3\end{array}$

The amount of ATP added here was $125 \mathrm{~g}$. mole per $10^{5} \mathrm{~g}$. protein.

The results of Fig.2 suggest that the preparation of $\mathrm{M}$-actomyosin studied here responds to ATP according to Equation ( 1 ), and then changes to reverse direction of Equation (1), as a result of decomposition of ATP. In these cases, not only the viscosity fall on addition of ATP was so quick, but the recovery of the viscosity was so rapid, that it was difficult to trace the initial change with the present viscometer. For these initial stages of the curves, extrapolation was made as shown by dotted lines along these curves. The values for relative viscosity at difinite points on the curves are shown in Table 1.

In Curve $\mathrm{A}$ of Fig. 2 where neither $\mathrm{Mg}$ ion nor $\mathrm{Ca}$ ion was present, the quickly restoring viscosity approached to its maximum value within 2 min. after adding ATP, and kept up a slow but steady increase until $30 \mathrm{~min}$. after, when the observation was stopped. In the presence of $\mathrm{Mg}$ ion, next to a less quick increase within $5 \mathrm{~min}$, the viscosity tended again to decrease (Curve $B$ ). The maximum value $\left(\eta_{1}\right)$ which was attained by the recovery was by far lower compared with the initial viscosity $(\eta)$. Also in the presence of $\mathrm{Ca}$ ion (Curve $\mathrm{C}$ ), the restoration of the earlier stages was very quick and the 
Table 1. Changes in relative viscosity of purified $\mathrm{M}$-actomyosin in $0.5 \mathrm{M} \mathrm{KCl}$ upon addition of ATP

(Calculated from Fig. 2)

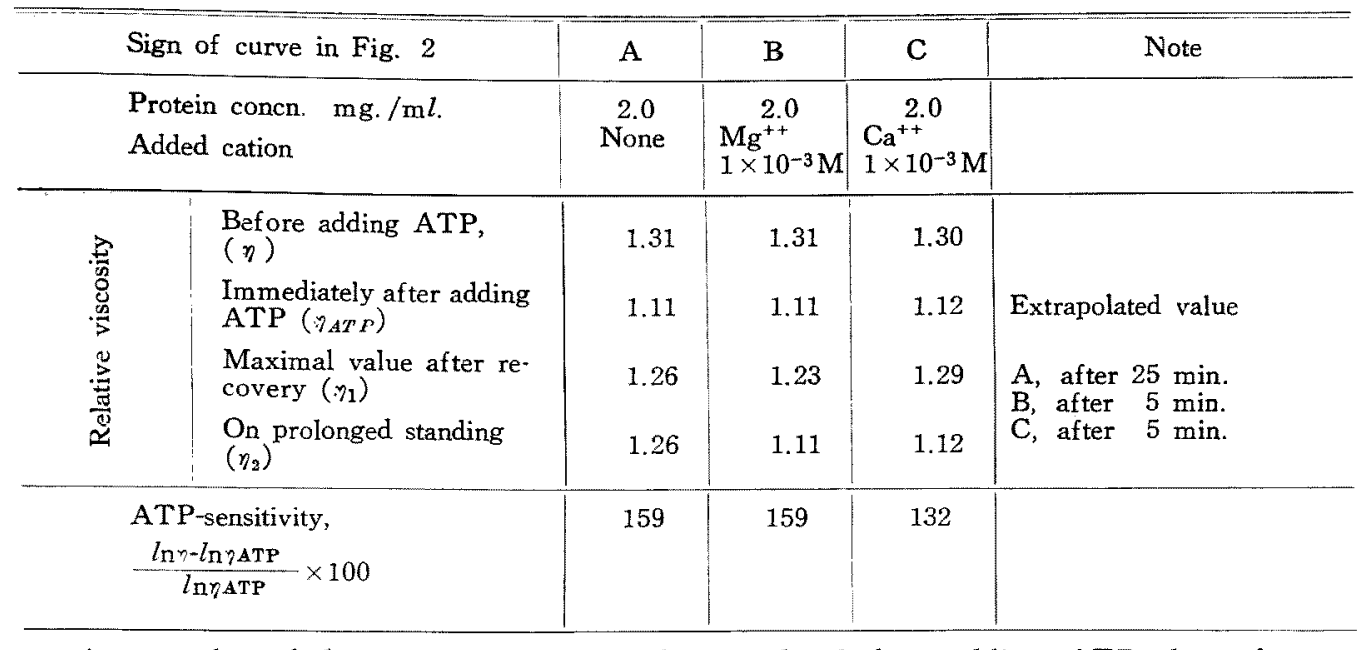

maximum :alue of the viscosity $\left(\eta_{1}\right)$ was close to that before adding ATP, but after 10 min., the once-restored viscosity resumed to fall, and reached a value which is close to that of the final stage of the case with $\mathrm{Mg}$ ion.

A control experiment where $1.0 \mathrm{~m} l$. of water instead of ATP solution was added, to the protein solution showed only a slight drop of viscosity, confirming the effect of ATP in the above experiments.

As a measure of the effect of ATP on viscosity, "ATPsensitivity",

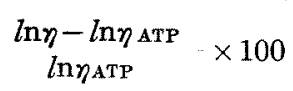

( $\eta$ and $\eta_{\text {ATP, }}$, relative viscosities before and after adding ATP) ${ }^{8}$, is shown in Table 1. The ATP-sensitivity of M-actomyosin of squid under experimental condition was 132 159 $\%$. These values are of a comparable order with thcse of actomyosins of rabbit $(60 \sim 180$ $\%)^{97}$ and carp $(116 \%)^{9 x}$.

\section{(C) Superprecipitation}

If ATP was added to the opalescent suspension of an M-actomyosin preparation at $I=0.12$, instantly the suspension became more transparent, and fine particulate aggregations were formed which deposited within 2 hours into a compact precipitate separating a clear mother liquid. Such a phenomenon was always found whether in the absence or presence of alkali earth metals. So it might be proved that this preparation shows a kind of superprecipitation. In these experiments the final concentrations of the components and other factors were as follows : Protein, $0.53 \mathrm{mg} . / \mathrm{ml}$. ATP, $1.8 \times 10^{-3} \mathrm{M} ; \mathrm{MgCl}_{2}$ and $\mathrm{CaCl}_{2}$, $1 \times 10^{-3} \mathrm{M} ; I, 0.12 ; \mathrm{pH}, 6.3 \sim 6.4$; temperature, $17^{\circ} \mathrm{C}$; ATP/protein, 340 g. mole $/ 10^{5} \mathrm{~g}$.

\section{Discussion}

The observed changes in SB and viscosity brought by added ATP stand in harmony with each other in supporting that dissociation of the protein molecule occurred like Equ- 
ation (1), though it is obscure whether the said actin and myosin are strictly identical with actin and myosin of rabbit or carp.

The results obtained suggest that ATPase activity of $\mathrm{M}$-actomyosin was prevented not only by the $\mathrm{Mg}$ ion of the studied concentration $\left(1 \times 10^{-3} \mathrm{M}\right)$, but at low temperature. The effect of $\mathrm{Ca}$ ion appeared to be activating though the data obtained was not so precise.

There is another interesting point as regards the effect of $\mathrm{Mg}$ and $\mathrm{Ca}$ ions. Namely, if $\mathrm{Mg}$ or $\mathrm{Ca}$ ion was present, the once-restored $\mathrm{SB}$ and viscosity resumed to decrease. Also in the absence of $\mathrm{Mg}$ and $\mathrm{Ca}$ ions, if ATP was once added, the once-restored SB has disappeared a night after, while SB of the control sample to which ATP was not added was always detected even after a night standing. In other words, if $\mathrm{M}$-actomyosin was brought to contact with ATP and a sort of dissociation was induced once, the protein has become less stable and might have been imposed with a tendency to reduce its asymmetry. Though the mechanism of these changes is obscure, the following appears to account in a general meaning for the consequences. If $\mathrm{M}$-actomyosin is once brought into contact with ATP, and is once dissociated into its components, possibly into actin and myosin, the latters are less asymmetric in shape and more random in orientation than M-actomyosin. Thus, even when M-actomyosin might be formed again, it might not beable to restore fully the highly asymmetric and stable configuration as it was before. Besides these causes, some necessary factors for the stability of $\mathrm{M}$-actomyosin might be lost. in the recombination product.

In Table 1 , values of $\eta_{2}$ of Curves $B$ and $C$ were close to those of $\eta_{A T P}$. This fact might suggest that there is some resemblance in molecular state of the protein between the stage where viscosity has fallen again and the stage immediately after the ATP addition. Thus, when viscosity has fallen again, $\mathrm{M}$-actomyosin might also have dissociated into its. components.

However, Yokoyama et al. ${ }^{10)}$ have reported a strange manner of viscosity change of myosin B fractions of scallop and other shellishes, and YAGI et al ${ }^{11}$. has shown some confronting results with similar materials. At any rate, it could be suggested that, also in the case of squid muscle proteins, the mechanism of ATP-responses are by no means simple, as the cases with other mollusks' muscles.

Though data on the effect of $\mathrm{Ca}$ and $\mathrm{Mg}$ ions on ATPase of myosin and actomyosin of rabbit seem complicated, some investigators agree in that it is activated with $0.0001 \sim$ $0.01 \mathrm{M} \mathrm{Ca}$ ion and inhibited with $0.00001 \sim 0.01 \mathrm{M} \mathrm{Mg}$ ion, both at the higher ionic strengths (e.g. $0.5 \mathrm{M} \mathrm{KCl})^{2) 3) 7 \text { ). }}$

As seen from the present data, the ATPase of $\mathrm{M}$-actomyosin of squid is also prevented by $\mathrm{Mg}$ ion ; so, the possibility that it might be activated by $\mathrm{Mg}$ ion has now been eliminated. Hence, the activation by $\mathrm{Mg}$ ion observed in the previous study might have possibly been due to a contamination with a kind of Mg-activated ATPase ${ }^{3 / 4) 5)}$. Further detailed study on ATPase activity will be treated in other report.

The ATPase activity of M-actomyosin has been found not to be of a new type as far as the effect of $\mathrm{Mg}$ ion is concerned, but the property that it is extracted easily with water from the muscle remains as a distinctive feature. 


\section{Summary}

1) On M-actomyosin preparation of squid muscle purified by reprecipitations, its responses of streaming birefringence (SB) and of viscosity to adenosinetriphosphate (ATP) added were studied togather with superprecipitation.

2) The changes of SB stood in harmony with those of viscosity, suggesting that dissociation and recombination of $\mathrm{M}$-actomyosin occurred successively when ATP was added. Superprecipitation was also confirmatively found with $\mathrm{M}$-actomyosin.

3) In the process of ATP-responses of SB and viscosity, the adenosinetriphosphatase (ATPase) activity of $\mathrm{M}$-actomyosin was found to be inhibited by $\mathrm{Mg}$ ion. It was shown that, as far as the effect of alkali earth metals on ATPase activity is concerned, M-actomyosin of squid is not distinct from actomyosin of rabbit and carp.

The author wishes to express his appreciation to Dr. M. Migita for his valuable advice, to Prof. S. Mizushima for his encouragement and to Miss. M. Akiba for the technical assistance.

\section{References}

1) Matcмото, J. J. : Bull. Jap. Soc. Sci. Fish., 23, 92 104 (1957).

2) Engelhardt, V.A. : "Advances in Enzymology", 6, 147 91 (1947).

3) BaIlex, K. : "The Proteins", Vol. II, Part B,. 951 1055, (1954).

4) Mommaerts, W. F. H. M. : "Muscular Contraction" Interscience Publisher, New York (1950) 96.

5) Kreley, W. W. and Meyerhof, O. : J. Biol. Chem., 176, 591 601 (1948).

6) Orada, M. and TADA, S. : Bull. Jap. Soc. Sci. Fish., 20, 224 31 (1954).

7) Wataxabe, S., Tonomura, Y. and Shomawa, H. : J.Biochem. (Jop.) ), 40, 387 402 (1953)

8) Weber, H. H. and Portzert, H. : "Advances in Protein Chemistry", 7, 211, 215, 236 (1952): Portzehl, H., Schramm, G. and Weber, H. H. : Z. Naturforsch., 5b, 61 74 (1950).

9) HaMolR, G. : "Contribution a l'étude des proteines musculaires de poissones", Imprimerie $\mathrm{H}$. Vaillent Carmanne. S. A., Liege (1955) 93: "Advances in Protein Chemistry", 10, 258(1955).

10) YokoYama, M., Terayama, Y. and NAGAI, T. : Kagaku, 22, 473 (1952).

11) Yagi, K., SASAKI, A. and MatsumiYa, H, J.Jop. Biochem. Soc, 26, 630 3 (1954). 